\title{
Expression of PCNA, p53 and Ki-67 in dentinogenic ghost cell tumors and calcifying cystic odontogenic tumors
}

\begin{abstract}
- Bianca de Fátima Borim Pulino Department of Stomatology, School of Dentistry, University of São Paulo, São Paulo, SP, Brazil • Carla Silva Siqueira Department of Stomatology, School of Dentistry, University of São Paulo, São Paulo, SP, Brazil • Carina Magalhães Esteves Duarte Department of Stomatology, School of Dentistry, University of São Paulo, São Paulo, SP, Brazil - Suzana Cantanhede Orsini Machado de Sousa Department of Stomatology, School of Dentistry, University of São Paulo, São Paulo, SP, Brazil
\end{abstract}

ABSTRACT | The aim of this study was to compare the proliferative pattern of dentinogenic ghost cell tumors (DGCT) and unicystic calcifying cystic odontogenic tumors (UCCOT) using antibodies against PCNA, p53 and Ki67. Three cases diagnosed as DGCT and ten as UCCOT were retrieved from the files of the Surgical Oral Pathology Service at the University of São Paulo, Brazil. Immunohistochemistry was performed in formalin-fixed and paraffin-embedded tissue specimens. Only nuclear staining was considered specific for the three antibodies. Immunoexpression of PCNA, Ki-67 and p53 was analyzed semi-quantitatively and quantitatively. The results showed that PCNA was positive in both lesions, mainly in the basal cells, and p53 showed positivity in all cases. UCCOT showed statistically significantly higher Ki-67 labeling indices than did DGCT. In conclusion, our results do not support the correlation between proliferative activity as shown by these proteins and reported biologic behavior.

DESCRIPTORS | Odontogenic Cyst, Calcifying; Cell Proliferation; Immunohistochemistry.

RESUMO | Expressão de PCNA, p53 e Ki-67 em tumor dentinogênico de células fantasmas e tumor odontogênico cístico calcificante unicístico • O objetivo deste estudo foi avaliar a expressão dos antígenos PCNA, p53 e Ki-67 (marcadores de proliferação), em três casos diagnosticados como tumor dentinogênico de células fantasma (TDCF) e dez casos como tumor odontogênico císticos, calcificante unicístico (TOCCU) obtidos dos arquivos do Serviço de Patologia Oral e Cirúrgica da Universidade de São Paulo, Brasil. Foram realizadas reações de imunohistoquímica em espécimes de tecido parafinado. Apenas a marcação nuclear foi considerada específica para os três anticorpos. A imunoexpressão das proteínas PCNA, p53 e Ki-67 foi analisada semi-quantitativamente e quantitativamente. Os resultados mostraram que o PCNA foi expresso em ambas as lesões, principalmente na camada basal, e que p53 também mostrou positividade em todos os casos. O TOCCU mostrou um aumento estatisticamente significante na expressão do Ki-67 em relação ao TDCF. Em conclusão, nossos resultados não mostraram correlação entre a atividade proliferativa e o comportamento biológico desses tumores.

DESCRITORES || Cisto Ondontogênico Calcificante; Proliferação de Células; Imunohistoquímica.

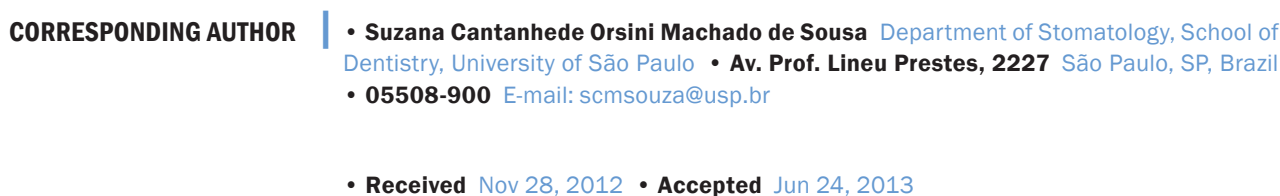




\section{INTRODUCTION}

Recently, the World Health Organization (WHO) has made changes in the classification of odontogenic tumors. Calcifying odontogenic cyst (COC) was re-named by Prætorius and LedesmaMontes $^{1}$ as calcifying cystic odontogenic tumor (CCOT) and the term dentinogenic ghost cell tumor (DGCT) was maintained by the same authors. ${ }^{1}$ Thus, CCOT was defined as a benign cystic neoplasm of odontogenic origin, characterized by an ameloblastoma-like epithelium with ghost cells that may calcify, ${ }^{1}$ and DGCT was defined as a locally invasive neoplasm characterized by ameloblastoma-like islands of epithelial cells in a mature connective tissue stroma. The nature of ghost cells has been studied by various authors with different explanations, such as a form of abnormal keratin formation, highly keratinized epithelial cells, true keratinization and cells which have lost their developmental and inductive effect. ${ }^{2}$ Cases previously called odontogenic ghost cell carcinomas and malignant epithelial odontogenic ghost cell tumors were re-named by the $\mathrm{WHO}^{3}$ as ghost cell odontogenic carcinomas (GCOC).

The CCOT is an uncommon benign odontogenic lesion that was first described by Gorlin et al. in 1962. ${ }^{4}$ In spite of being called cyst, there is no consensus in the literature as to its classification as a cyst or tumor. ${ }^{5}$ Histologically, the cyst wall is lined by a thin ameloblastic epithelium and eosinophilic cells with no obvious nuclei, called "ghost cells," which in turn may be calcified. In the adjacent fibrous area, epithelial proliferation and odontogenic dysplastic dentin can be observed. ${ }^{6}$

The DGCT is a rare odontogenic epithelial neoplasm considered the neoplastic counterpart of CCOT.7 Histologically, the presence of ghost cells within the proliferating ameloblastic epithelium is the essential feature for diagnosis. Varying amounts of dysplastic dentin are present in the surrounding stroma, as well as in close contact with the epithelial islands or ghost cells. In addition, dysplastic calcifications can be found. ${ }^{8}$

The study of oncogenes and tumor suppressor genes such as p53, which are involved in the checkpoints of cell growth, can improve understanding of the biological behavior of DGCT.

PCNA (proliferating cell nuclear antigen) is a non-histone nuclear protein required for DNA synthesis and is an accessory protein for DNA polymerase-alpha, which is found at high levels during the G1/S cell cycle. It is synthesized in the cell nucleus and has a key role in cell cycle initiation. PCNA is the protein most used to evaluate cell proliferation immunohistochemically, since it is undetectable in cells that are out of the cell cycle. The incidence of PCNA expression is correlated with mitotic activity. ${ }^{9,10}$

The Ki-67 antigen is expressed in all phases of the cell cycle, except Go. Its expression rises with progression of the cell cycle, increasing during the second half of the S phase, reaching a peak in G2 and $\mathrm{M}$ and decreasing rapidly after mitosis. Thus the expression of Ki-67 reflects the number of proliferating cells in a tissue. ${ }^{11}$ Non-dividing or "resting" cells in the Go phase are Ki-67 antigen negative. ${ }^{9}$

The p53 protein consists of a tetramer that is accumulated in the cytoplasm during the G1 phase of the cell cycle and migrates to the nucleus in the early S phase, which occurs at one important checkpoint in the cell's DNA. When the DNA molecule has been damaged or the cell is in a stress condition, there is an overexpression of the p53 protein. In the nucleus, p53 acts as a transcription factor to activate several genes. When it is not possible to correct errors in the DNA molecule, p53 activates pathways inducing apoptosis. ${ }^{12}$

\section{OBJECTIVE}

The objective of the present study was to evaluate the proliferative activity of DGCT comparing it to that of CCOT using PCNA, p53 and Ki-67. 


\section{MATERIALS AND METHODS}

Three cases diagnosed as DGCT and ten as simple, unicystic CCOT, were retrieved from the files of the Surgical Oral Pathology Service at the University of São Paulo. This manuscript has been approved by the university's research ethics committee, number 88/11 and CAAE 0099.0.017.000-11.

Immunohistochemistry was performed in formalin-fixed and paraffin-embedded tissue specimens. Three- $\mu \mathrm{m}$ sections were obtained, deparaffinized in xylenes and hydrated in alcohols of decreasing concentration. Antigen retrieval was performed using a heated $\mathrm{pH} 6.0$ citrate buffer (for PCNA), a pH 8.o TRIS EDTA TWEEN 20 (for p53) or a pH 9.o EDTA (for Ki-67). After cooling to room temperature, and in order to block endogenous peroxidase activity, sections were immersed twice for 15 minutes in $\mathrm{H}_{2} \mathrm{O}_{2}$ and methanol (1/1). After rinsing in TRIS buffer, $\mathrm{pH} 7.6$, three times, for $10 \mathrm{~min}$ utes each, the sections were incubated with primary antibodies as follows:

- PCNA (mouse monoclonal antibody, clone PC10, Dako, Carpinteria, CA, USA) in a dilution of 1:100 for 60 minutes;

- Ki-67 (mouse monoclonal antibody, clone MIB-

1, Dako, Carpinteria, CA, USA) in a dilution of 1:75 for 60 minutes;

- p53 (mouse monoclonal antibody, clone DO7, Dako, Carpinteria, CA, USA) in a dilution of 1:50 for 120 minutes.

In the next stage, a biotinyl antibody was used in the reaction and then a streptavidin-peroxidase complex (LASB ${ }^{\circledR}$ + System - HRP, Dako, Carpinteria, CA, USA) was applied. The antigen-antibody complex was visualized using DAB chromogen (3'3- diamonobenzidine, cat. no. S30oo, Dako, Carpinteria, CA, USA). Positive (oral squamous cell carcinoma sections) and negative (omission of the antibody) controls were included in all the reactions.
Only nuclear staining was considered specific for the three antibodies. Protein expression was assessed using a light microscope at a magnification of 40x. Protein immunoexpression of PCNA, Ki-67 and p53 was analyzed semiquantitatively based on the criteria of Rahman et al. (2010) ${ }^{13}$ that consists of

- low (score 0: negative; score $+1:<20 \%$ ),

- moderate (score $+2: \geq 20$ and $<50 \%$ ), and

- high (score $+3: \geq 50 \%$ ) expressions.

For quantitative analysis, all slides were observed under a light microscope and positive cells for anti-PCNA, anti-p53 and anti-Ki-67 were counted in a randomly selected field, choosing the most positive spots. Thus, sections were examined under a microscope and captured through an Axio Imager A2 (Zeiss Carl Zeiss Microscopy GmbH, Jena, Germany) with a digital camera attached (Zeiss - Axio Cam HRc ${ }^{\circledR}$ Carl Zeiss Microscopy GmbH Jena, Germany) and the aid of Axio Vision software (Zeiss) at 400× magnification.

\section{RESULTS}

\section{Qualitative analysis}

Histologically, CCOT showed a cystic capsule lined by an epithelium presenting a well-defined basal layer of columnar cells, an overlying layer that usually resembled stellate reticulum and masses of ghost epithelial cells present in the epithelial lining or in the fibrous capsule. Calcified areas were present (Figure 1A). Immunohistochemical reactions showed that PCNA was expressed by basal cells of the cystic lining epithelium. p53 showed positivity in all cases with a few positive cells. Ki-67 was positive in a few cells of the basal cell layer in all cases (Figures 1B and 1C). DGCT was represented histologically by the presence of large amounts of an amorphous eosinophilic material (dentinogenic-like), interspersed by an "ameloblastoma-like" odontogenic epithelium and by groups of ghost cells (Figure 2A). As for CCOT, PCNA was expressed by 

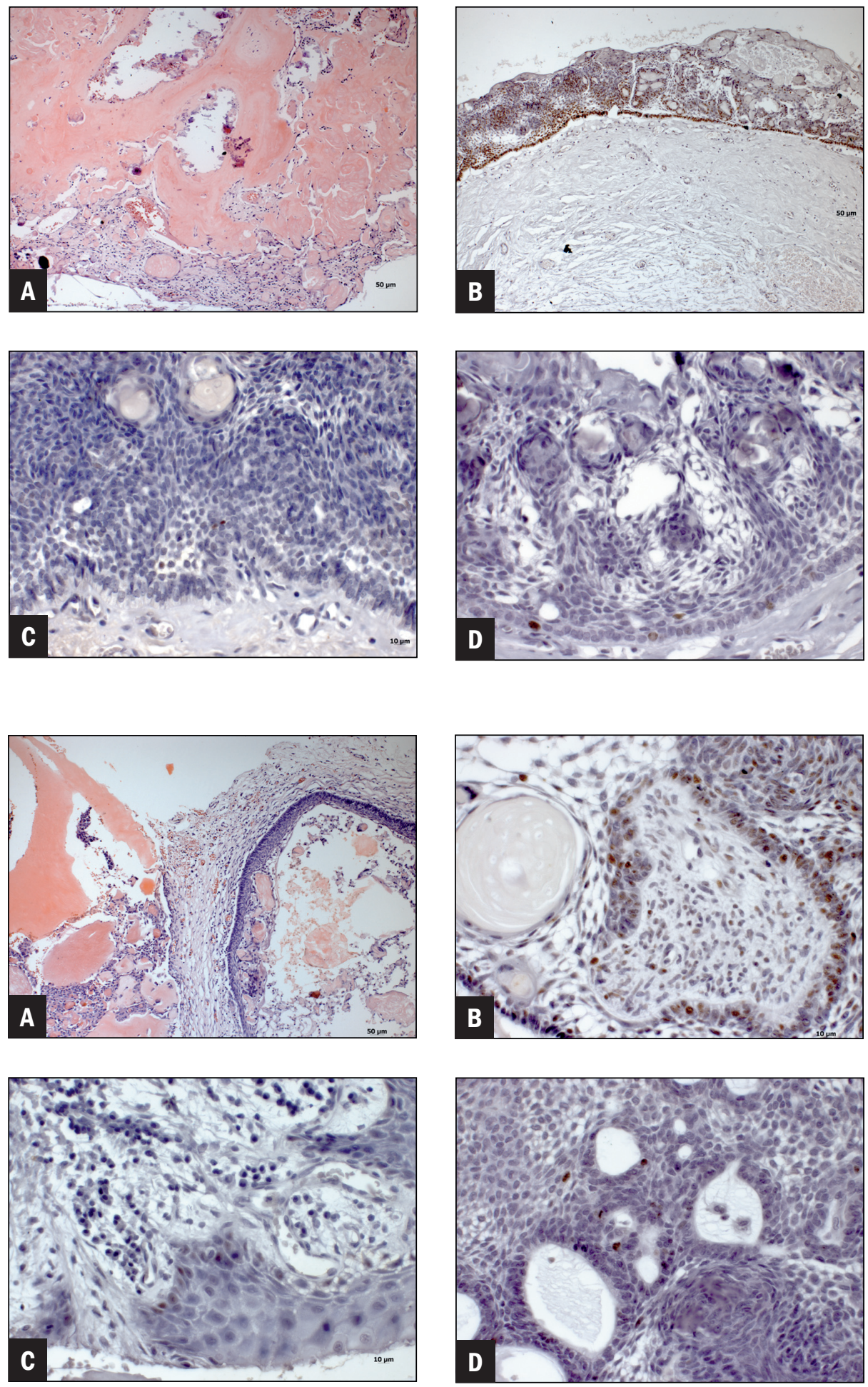

Figure 1 Histopathology characteristics of CCOT showing a cystic lesion with a large amount of amorphous material and calcified areas $(\mathbf{A})$. PCNA shows a strong expression in all odontogenic epithelium (B). p53 shows a weak expression with a few positive cells (arrows, C). Ki-67 also presents a weak expression, mostly in the basal layer of the odontogenic epithelium (D).

Figure 2 | Histopathology characteristics of DGCT showing the presence of ghost cells within the proliferating ameloblastic epithelium. Eosinophilic dentinoid material seen adjacent to the surrounding stroma, dysplastic calcifications and ghosts cells $(\mathbf{A})$. PCNA is strongly expressed, mainly in the basal layer of the odontogenic epithelium (B). The marking of p53 appeared weak in all cases with the rare presence of positive cells $(\mathbf{C})$. Ki-67 is expressed by a few cells of the odontogenic epithelium (arrows, D). basal cells of the odontogenic epithelium (Figure 2B), while p53 showed positivity in all cases (Figure 2C), as did Ki-67 (Figure 2D).
Table 1 shows the score grading of DGCT for the immunoreactions with each antibody and Table 2 shows the same for CCOT. 
Table 1 Expression of PCNA, Ki-67 and p53 in DGCT cases.

\begin{tabular}{c|c|c|c} 
& $\begin{array}{c}\text { Expression of } \\
\text { Ki-67 }\end{array}$ & $\begin{array}{c}\text { Expression of } \\
\text { p53 }\end{array}$ & $\begin{array}{c}\text { Expression of } \\
\text { PCNA }\end{array}$ \\
\hline DGCT 1 & +1 & 0 & +3 \\
\hline DGCT 2 & +1 & +1 & +1 \\
\hline DGCT 3 & +1 & +1 & +3 \\
\hline
\end{tabular}

\section{Statistical analysis}

Exploratory data analyses were performed. The comparison between CCOT and DGCT was performed using the nonparametric Mann-Whitney test.

Comparing the positive cells counted of CCOT and DGCT, there were no significant differences between these two types of tumors in relation to PCNA ( $p=0.5541)$ or in relation to $\mathrm{p} 53$ ( $p=0.0503)$. However, cell count was significantly higher for Ki-67 when comparing CCOT and DGCT scores $(p=0.0336)$.

\section{DISCUSSION}

Since CCOT was characterized by Gorlin ${ }^{4}$ in 1962 as a separate entity, the true nature of this lesion has been controversial in the literature, without a consensus about its classification as a cyst or tumor.

CCOT accounts for $1 \%-2 \%$ of all odontogenic tumors, whereas $2 \%-14 \%$ are classified as DGCT. ${ }^{14}$ These lesions are characterized by a well-delineated cystic proliferation of the odontogenic epithelium with ghost cells, which are degenerated epithelial cells, usually calcified. It is known that this calcification of odontogenic epithelium is dystrophic. However, dentinoid or bone-like hard tissues have sometimes been reported to be formed in the cyst wall. ${ }^{15}$ The solid counterpart of CCOT is more aggressive and is not compatible with a cyst, tending to local recurrence after curettage. ${ }^{16}$

DGCT is an odontogenic epithelial neoplasm, considered the neoplastic counterpart of CCOT for
Table 2 || Expression of PCNA, Ki-67 and p53 proteins in CCOT cases.

\begin{tabular}{|c|c|c|c|}
\hline & $\begin{array}{c}\text { Expression of } \\
\quad \mathrm{Ki}-67\end{array}$ & $\begin{array}{l}\text { Expression of } \\
\text { p53 }\end{array}$ & $\begin{array}{c}\text { Expression of } \\
\text { PCNA }\end{array}$ \\
\hline ССОТ 1 & 0 & +1 & +2 \\
\hline ссот 2 & 0 & +1 & +3 \\
\hline сСОт 3 & +1 & +1 & +3 \\
\hline ССОТ 4 & +1 & +1 & +3 \\
\hline ССОТ 5 & +1 & +1 & +3 \\
\hline ССОт 6 & +1 & +1 & +3 \\
\hline ссот 7 & +1 & +2 & +3 \\
\hline Ссот 8 & +1 & +2 & +3 \\
\hline ССОт 9 & 0 & +1 & +3 \\
\hline ссот 10 & +1 & +1 & +3 \\
\hline
\end{tabular}

being locally aggressive. ${ }^{7}$ DGCT often occurs as an intraosseous variant and less commonly as extraosseous. Extra-osseous lesions affect the gingivae and are usually asymptomatic. Their behavior is typically less aggressive and can be controlled by local excision. Intraosseous DGCT is more aggressive and local resection is recommended with a wider margin. There is no predilection for regions of the maxilla and mandible; however, $75 \%$ of the cases affect men. The etiology remains unclear. ${ }^{16,17}$ A few studies have been published comparing invasiveness and proliferation of these neoplasms. Gong et al. (2009) ${ }^{18}$ evaluated the nuclear expression of NF kappaB, MMP9 and Ki-67 in CCOT, DGCT and ghost cell odontogenic carcinoma. In the present study, no statistically significant difference in the expression of the proliferation markers between CCOT and DGCT was found, except for Ki-67 that was more expressed in CCOT. However, due to the rarity of DGCT and, consequently, the low number of cases analyzed, results must be examined with caution.

Motosugi et al. (2009) ${ }^{19}$ analyzed the hypothesis of a malignant transformation from calcifying odontogenic cyst to ghost cell odontogenic carcinoma (GCOC) and evaluated the expression of p53 
and Ki-67 in these tumors, showing that the expression of Ki-67 was also slightly positive in cases of GCOC, not only in cases of CCOT and DGCT.

In contrast to the present study that did not show any difference for the immunoexpression of p53 and PCNA in the studied cases, Saghafi et al. $(2010)^{10}$ performed immunohistochemical studies of p53 antigen and PCNA in all types of CCOT, based on the division proposed by Prætorius in $1981 .{ }^{20}$ A higher expression of both p53 and PCNA in the solid variant was observed, while the cystic variant had a low expression.

Non-mutated p53, a protein that monitors the integrity of the genome, is not detected by immunohistochemical methods. Mutated or inactivated p53, on the contrary, can be shown in the tissues and could increase the pool of proliferative cells. ${ }^{21}$ This fact may explain our results in which a few positive cells were present, showing that cells may present increased proliferation without detectable

\section{REFERENCES}

1. Prætorius F, Ledesma-Montes C. Calcifying cystic odontogenic tumour. In: Barnes L, Eveson JW, Reichart P, Sidransky D, editors. World Health Organization classification of tumours. Pathology and genetics of head and neck tumours. Lyon: IARC Press; 2005. p. 313.

2. Mehendiratta M, Bishen KA, Boaz K, Mathias Y. Ghost cells: Ajourney in the dark. Dent Res J. 2012 Dec;9 (Suppl 1):S1-8.

3. Takata T, Lu Y. Ghost cell odontogenic carcinoma. In: Barnes L, Eveson JW, Reichart HP, Sidransky D, editors. World Health Organization classification of tumours. Pathology and genetics of head and neck tumours. Lyon: IARC Press; 2005. p. 293.

4. Gorlin RJ, Pindborg JJ, Clause FP, Vickers RA. The calcifying odontogenic cyst--a possible analogue of the cutaneous calcifying epithelioma of Malherbe: an analysis of fifteen cases. Oral Surg Oral Med Oral Pathol. 1962 Oct;15:1235-43.

5. Fregnani ER, Pires FR, Quezada RD, Shih IeM, Vargas PA, de Almeida OP. Calcifying odontogenic cyst: clinicopathological features and immunohistochemical profile of 10 cases. J Oral Pathol Med. 2003 Mar;32(3): 163-70 . alterations of the p53 gene. Another interesting fact that could explain the decreasing proliferation of p53 is the methylation showed by Moreira et al. $(2009)^{22}$ in $33.33 \%$ of CCOT. However, it is not possible to establish that epigenetic is a common event in these tumors.

The explanation for the high PCNA expression and low expression of $\mathrm{Ki}-67$, both proliferation markers, is that PCNA expression can be correlated with mitotic activity, ${ }^{9,10}$ while Ki-67 decreases rapidly after mitosis. Therefore, we believe that the increased activity of these tumors occurs soon after the process of mitosis.

\section{CONCLUSIONS}

In conclusion, our results show that both tumors had the same benign behavior and our findings do not support a correlation between proliferative activity as shown by these proteins and reported biologic behavior.

6. Reyes D, Villanueva J, Espinosa S, Cornejo M. Odontogenic calcificant cystic tumor: a report of two clinical cases. Med Oral Patol Oral Cir Bucal. 2007 Mar 1;12(2):e126-9.

7. Kim SA, Ahn SG, Kim SG, Park JC, Lee SH, Kim J, et al. Investigation of the beta-catenin gene in a case of dentinogenic ghost cell tumor. Oral Surg Oral Med Oral Pathol Oral Radiol Endod. 2007 Jan;103(1):97101.

8. Yoon HJ, Jayasooriya P, Hong SD, Lee JI, Hong SP. Clinico-pathologic conference: case 5. Dentinogenic ghost cell tumour (DGCT). Head Neck Pathol. 2010 Dec;4(4):347-50.

9. Czyzewska J, Guzińska-Ustymowicz K, Pryczynicz A, Kemona A, Bandurski R. Immunohistochemical evaluation of $\mathrm{Ki}-67, \mathrm{PCNA}$ and $\mathrm{MCM}^{2}$ proteins proliferation index (PI) in advanced gastric cancer. Folia Histochem Cytobiol. 2009;47(2):289-96.

10. Saghafi S, Zare-Mahmoodabadi R, Salehinejad J, Kadeh H, Afzal-Aghaee M. Immunohistochemical analysis of p53 and PCNA expression in calcifying odontogenic cyst. J Oral Sci. 2010 Dec;52(4):609-13. 
11. de Vicente JC, Torre-Iturraspe A, Gutiérrez AM, LequericaFernández P. Immunohistochemical comparative study of the odontogenic keratocysts and other odontogenic lesions. Med Oral Patol Oral Cir Bucal. 2010 Sep 1;15(5):e709-15 .

12. el-Deiry WS, Tokino T, Velculescu VE, Levy DB, Parsons R, Trent JM, et al. WAF1, a potential mediator of p53 tumor suppression. Cell. 1993 Nov 19;75(4):817-25.

13. Rahman MM, Qian ZR, Wang EL, Yoshimoto K, Nakasono M, Sultana R, et al. DNA methyltransferases 1, 3a, and 3b overexpression and clinical significance in gastroenteropancreatic neuroendocrine tumors. Hum Pathol. 2010 Aug;41(8):106978.

14. Stone CH, Gaba AR, Benninger MS, Zarbo RJ. Odontogenic ghost cell tumor: a case report with cytologic findings. Diagn Cytopathol. 1998 Mar;18(3):199-203.

15. Murakami S, Koike Y, Matsuzaka K, Ohata H, Uchiyama T, Inoue $\mathrm{T}$. A case of calcifying odontogenic cyst with numerous calcifications: immunohistochemical analysis. Bull Tokyo Dent Coll. 2003 May;44(2):61-6.

16. Sun G, Huang X, Hu Q, Yang X, Tang E. The diagnosis and treatment of dentinogenic ghost cell tumor. Int J Oral Maxillofac Surg. 2009 Nov;38(11):1179-83 .
17. Candido GA, Viana KA, Watanabe S, Vencio EF. Peripheral dentinogenic ghost cell tumor: a case report and review of the literature. Oral Surg Oral Med Oral Pathol Oral Radiol Endod. 2009 Sep;108(3):e86-90.

18. Gong Y, Wang L, Wang H, Li T, Chen X. The expression of NF-kappaB, Ki-67 and MMP-9 in CCOT, DGCT and GCOC. Oral Oncol. 2009 Jun;45(6):515-20 .

19. Motosugi U, Ogawa I, Yoda T, Abe T, Sugasawa M, Murata S, et al. Ghost cell odontogenic carcinoma arising in calcifying odontogenic cyst. Ann Diagn Pathol. 2009 Dec;13(6):394-7.

20. Prætorius F, Hjørting-Hansen E, Gorlin RJ, Vickers RA. Calcifying odontogenic cyst. Range, variations and neoplastic potential. Acta Odontol Scand. 1981;39(4):227-40.

21. Piattelli A, Fioroni M, Di Alberti L, Rubini C. Immunohistochemical analysis of a dentinogenic ghost cell tumour. Oral Oncol. 1998 Nov;34(6):502-7.

22. Moreira PR, Guimarães MM, Gomes CC, Diniz MG, Brito JA, de Castro WH, et al. Methylation frequencies of cell-cycle associated genes in epithelial odontogenic tumours. Arch Oral Biol. 2009 Oct;54(10):893-7. 